\title{
Sudans sidste chance for varig fred
}

\section{Peter Kagwanja og Thomas N. Kimaru}

\section{Store spændinger om folkeafstemninger i januar truer med at kaste Sudan tilbage i borgerkrig. Øget våbenkapløb imellem Syd- og Nordsudan er blandt faresignalerne}

Sudan står over for afgørende folkeafstemninger 9. januar 2011, der afgør om Sydsudan vil forblive en del af landet eller være en uafhængig enhed. Samme dag vil befolkningen i den olierige Abyei-region stemme om, hvorvidt regionen skal tilsluttes Nord eller Syd. Men øget etnisk vold, et nord-syd våbenkapløb, dødvande i skabelsen af afstemningsmekanismer og trusler fra det herskende National Congress Party (NCP) om at ignorere resultaterne af folkeafstemningerne truer med at kaste Sudan tilbage i borgerkrig.

FN's seneste generalforsamling i New York fremhævede Sudans kommende historiske folkeafstemninger som sidste chance for en varig fred. Khartoums naboer og det internationale samfund i almindelighed må handle hurtigt og beslutsomt for at sikre fredelige og troværdige folke- afstemninger og insistere på, at parterne accepterer resultaterne for at forhindre en glidebane tilbage til borgerkrigstilstande.

Siden den politiske pluralismes komme tidligt i 1990'erne er folkeafstemninger blevet et vigtigt redskab for folkeligt demokrati. De har løst uenigheder, afsluttet borgerkrige og fremmet freden i Afrika. I de sidste to årtier har det skrøbelige kontinent oplevet adskillige folkeafstemninger fra Burundi i 1991 til Eritrea i 1993, Senegal i 2001, Den Demokratiske Republik Congo, Egypten, Uganda og Kenya i 2005 og senest Zanzibar og Kenya i 2010.

Mens folkeafstemninger er et uadskilleligt træk ved den seneste bølge af demokrati, har resultaterne været blandede i lande, der er kommet ud af årtiers autoritært styre, konflikter og folkemord som fejlslagne stater. 
På den ene side opstod Eritrea som Afrikas 54. stat, da 99,8 procent at dets borgere stemte for uafhængighed i 1993. Direkte folkevalg hyldes nu som vejen til at løse nationale problemer som etnisk diskriminering og marginalisering, for eksempel i et land som Elfenbenskysten. Folkeafstemninger har desuden været brugt til at vedtage nye forfatninger efter undertrykkelse, sammenbrud i institutioner, etnisk vold eller borgerkrig i Den Demokratiske Republik Congo, Sydafrika og Kenya. Direkte valg har også været brugt i (endnu fejlslagne) forsøg på at løse Vestsaharas separatistiske afvisning af tilknytning til Marokko.

På den anden side udløste den fejlslagne folkeafstemning om en ny forfatning i Kenya i 2005 en voldsom skærpelse af hadet imellem stammer og plantede frøene til kaos efter valget i 2008, hvor over 1.000 kenyanere blev dræbt og over 600.000 drevet på flugt. Og efter fem folkeafstemninger om en forfatning, er udviklingen af demokrati i Madagascar stagneret med magtkamp i eliten og politisk lammelse, der kulminerede i marts 2009, da oppositionen med støtte fra militæret greb magten. I Niger udløste en kontroversiel folkeafstemning i august 2009 en forfatningsmæssig og politisk krise, der endte med et militærkup i februar 2010.

De forestående folkeafstemninger i regionerne Sydsudan og Abyei er nu de seneste forsøg i Afrika på at løse en langstrakt konflikt og opnå en bæredygtig fred gennem direkte demokrati.

\section{Fredsaftale}

Den epokegørende Comprehensive Peace Agreement (CPA), der i 2005 blev underskrevet i den kenyanske by Naivasha mellem National Congress Party (NCP) og Sudan People's Liberation Movement (SPLM), afsluttede ikke blot Afrikas mest dødbringende og længste borgerkrig, men gav også Syden retten til at træffe beslutning om uafhængighed og Abyei ret til at beslutte, om det vil være del af Nord eller Syd. Men fortsatte nord-syd brydninger bringer folkeafstemningerne i fare.

Mindre end fire måneder før folkeafstemningen blev der skabt en valgkommission i Sydsudan med tre års forsinkelse. I oktober 2010 havde man endnu ikke startet registrering af vælgere eller andre større logistiske forberedelser.

Valgkommissionens arbejde er blandt andet forhindret af et nordsyd slagsmål om posten som dens generalsekretær. Selv efter at Sydsudan accepterede en kandidat fra Nord, Mohammed Othman al-Nijoumi, til posten, fortsatte opfattelsen, at Nordsudan vil svindle med resultatet, med at skabe problemer. Desuden har diverse manøvrer og opflammende udtalelser fra både Khartoum og Juba på nyttesløs vis ophedet den politiske temperatur 
og spændingerne op til folkeafstemningerne i januar.

For nylig pustede Haj Majib Suwar, Khartoums minister for unge og sport og ledende medlem af præsident Omar Hassan al-Bashirs NCP, til følelserne i Syd ved at sige: "Vi vil måske slet ikke anerkende resultatet af folkeafstemningerne".

Pinger fra NCP har anklaget SPLM for at indskrænke ytringsfriheden og ikke tillade fri kampagne i Syd og for at arrestere og chikanere folk, der taler for enhed samt for at akkumulere tropper i strategiske områder.

På sin side har SPLM's ledelse anklaget Khartoum for at forsøge at fastholde dets bastioner i Syd. Herom har Koul Diem Koul, talsmand for SPLM, sagt, at "det, som vi hører Suwar sige, er en erklæring fra en besættelsesmagt, der ønsker at besætte mere land”. Og på samme vis har SPLM truet med at søge 'alternative måder' til, at folk i Syd kan udøve deres ret til selvbestemmelse, herunder muligheden for en ensidig uafhængighedserklæring, hvis Nord undergraver folkeafstemningen i januar.

Den trussel har NCP betegnet som 'politisk selvmord'.

\section{Folkeafstemning i Abyei}

Et accelererende våbenkapløb mellem Nord og Syd opheder yderligere situationen, da det viser, at de to rivaler forbereder sig på en mulig tilbagevenden til borgerkrig. Både Juba og Khartoum har brugt betydelige summer af deres andele af olieindtægterne til at købe våben.

Abyeis folkeafstemning om hvorvidt den olierige region skal tilslutte sig Juba eller Khartoum, er også under belejring. Forberedelserne gik i dødvande, da det mislykkedes for NCP og SPLM at enes om etableringen af en valgkommission i Abyei. I centrum for nord-syd konflikten om Abyei er den klassiske splittelse mellem indvandrere og lokale. Både fredsaftalen i 2005 og Abyeis lov om folkeafstemninger giver stemmeret til Abyeis 'indfødte', der defineres som Ngok Dinka stammen. Men det komplicerer sagen yderligere, at loven også tillader, at folkeafstemningskommissionen afgør, hvilke 'andre sudanesere', som kan anses for at være fastboende med stemmeret.

I 2009 bekræftede den permanente voldgiftsdomstol i Haag, at byen Abyei er kerneland for Ngok Dinka, men de ændrede grænser lader flertallet i Missirya uden for regionen og således uden stemmeret. Både SPLM og NCP enedes dengang om at respektere domstolens afgørelse.

I overensstemmelse hermed har SPLM stillet spørgsmålstegn ved, om nomaderne i Missirya har stemmeret. De fleste af nomaderne græsser deres kvæg i syd i tørre perioder. SPLM har anklaget Khartoum for at have smuglet 75.000 nomader ind $\mathrm{i}$ området for at ændre stemmedemografien og skubbe resultatet af folke- 
afstemningen i Nordsudans favør. De genbevæbnede Sudanese Armed Forces og Sudan People's Liberation Army har positioneret sig omkring strategiske oliefelter i et endnu stille slag om oliereserverne i tilfælde af vold efter afstemningen.

SPLM har også anklaget præsident al-Bashirs NCP for at stå bag stedfortræderkrige imellem etniske grupper i Syd som led i et del og hersk spil. Alene i 2009 kostede kampe imellem etniske grupper i Syd over 2.500 liv og fordrev over 400.000 mennesker. Spændinger om græsningsområder og vand samt tyveri af kvæg har skabt nye brudlinjer, der kan udnyttes til at skærpe konflikterne. Desuden har slagsmål om magtpositioner, kontrol med ressourcer og anklager om svindel ved de meget omstridte valg $i$ april 2010 intensiveret Syd-Syd konflikten med en mere splittet Sydsudan som resultat.

\section{International indgriben}

Sudans naboer, panafrikanske organisationer og det internationale samfund må nu handle konsekvent og hurtigt for at forhindre, at Sudan synker tilbage i borgerkrig. Sudans naboer, der anerkender Sydsudans ret til selvbestemmelse, især Kenya, Uganda, Eritrea og Etiopien, indser også, at stabilitet på Afrikas Horn hænger snævert sammen med Sudans fremtid.

Det er forudsigeligt, at øgede kon- flikter i Sudan vil have alvorlige konsekvenser for den øvrige region, herunder flygtningestrømme, ødelæggelse af potentielle markeder og handel, især med olie.

Sudans naboer bør derfor bruge de bedste erfaringer fra afvikling af folkeafstemninger andre steder $\mathrm{i}$ Afrika til at hjælpe Sydsudans og Abyeis valgkommissioner med at afvikle succesrige folkeafstemninger. Sudan kan drage vitale lærer af

Kenyas yderst succesfulde folkeafstemning om forfatningen 4 . august 2010, især når det gælder registrering af vælgere, sikkerhed omkring valgkampagner og styring af afstemningsprocessen. Desuden kan erfaringerne fra folkeafstemningen $\mathrm{i}$ 1993, der førte til Eritreas løsrivelse fra Etiopien, være af stor værdi for både Juba og Khartoum.

Desuden må regionale institutioner som fx den Afrikanske Union (AU) intensivere deres diplomatiske bestræbelser for at løse op for hårdknuden om dannelse af en folkeafstemningskommission i Abyei og sætte skub i den forsinkede vælgerregistrering. Især må AU's High Level Implementation Panel for Sudan, der er ledet af Sydafrikas tidligere præsident Thabo Mbeki, øge sine bestræbelser for overvågning af vælgerregistreringen og øge panelets jæunlige mæglinger for at løse de sydende konflikter.

24. september 2010 holdt FN's Generalforsamling et møde om Sudan, hvor retten til selvbestem- 
melse for befolkningerne i Sydsudan og Abyei blev understreget. USA's præsident, Barack Obama, stod i spidsen for globale ledere i understregning af betydningen af fredelige folkeafstemninger for $\mathrm{Su}$ dan og for hele den skrøbelige region, Afrikas Horn.

USA og EU må også øge det diplomatiske pres på parterne, institutionerne og enkeltpersonerne, der underminerer mulighederne for, at folkeafstemningerne går glat. De må i den forbindelse overveje målrettede sanktioner. At sikre frie, fair og gennemskuelige folkeafstemninger og lægge pres på de involverede parter for at acceptere afstemningsre- sultaterne er helt centralt for at forhindre genopblussen af borgerkrig.

Peter Kagwanja er leder af Africa Policy Institute, Johannesburg, og rådgiver $i$ sikkerhed og regeringsudøvelse.

Thomas N. Kimaru er politisk analytiker ved Africa Policy Institute med sarlig forskningsinteresse i Sudan.

Ved redaktionens afslutning var der tale om at udskyde folkeafstemningerne pga. forsinket valgerregistrering og andre logistiske problemer.

(Oversat fra engelsk af Vibeke Sperling) 